\title{
Title
}

\section{Evaluation of a speech-based Al system for early detection of Alzheimer's disease remotely via smartphones}

\section{Author names}

Emil Fristed ${ }^{1}$, Caroline Skirrow ${ }^{* 1}$, Marton Meszaros ${ }^{1}$, Raphael Lenain ${ }^{1}$, Udeepa

Meepegama $^{1}$, Stefano Cappa ${ }^{2,3}$, Dag Aarsland ${ }^{4,5}$, Jack Weston ${ }^{1}$

\section{Affiliations}

${ }^{1}$ Novoic Ltd, London, UK.

${ }^{2}$ IUSS Cognitive Neuroscience (ICoN) Center, University School for Advanced Studies ${ }^{3}$ IRCCS Mondino Foundation, Pavia, Italy

${ }^{4}$ Department of Old Age Psychiatry, Institute of Psychiatry, Psychology \& Neuroscience, King's College London

${ }^{5}$ Centre for Age-Related Diseases, Stavanger University Hospital, Norway

*corresponding author: caroline@novoic.com

\section{Abstract}

Background: Changes in speech, language, and episodic and semantic memory are documented in Alzheimer's disease (AD) years before routine diagnosis.

Aims: Develop an Artificial Intelligence (AI) system detecting amyloid-confirmed prodromal and preclinical $A D$ from speech collected remotely via participants' smartphones.

Method: A convenience sample of 133 participants with established amyloid beta and clinical diagnostic status (66 A $\boldsymbol{\beta}+, 67 \mathrm{~A} \boldsymbol{\beta}$-; 71 cognitively unimpaired (CU), 62 with mild cognitive impairment $(\mathrm{MCl})$ or mild $A D)$ completed clinical assessments for the AMYPRED study (NCT04828122). Participants completed optional remote assessments daily for 7-8 days, including the Automatic Story Recall Task (ASRT), a story recall paradigm with short and long variants, and immediate and delayed recall phases. Vector-based representations from each story source and transcribed retelling were produced using ParaBLEU, a paraphrase evaluation model. Representations were fed into logistic regression models trained with tournament leave-pair-out cross-validation analysis, predicting $A \boldsymbol{\beta}$ status and $\mathrm{MCl} / \mathrm{mild} \mathrm{AD}$ within the full sample and $\mathrm{A} \boldsymbol{\beta}$ status in clinical diagnostic subsamples.

Findings: At least one full remote ASRT assessment was completed by 115 participants (mean age=69.6 (range 54-80); 63 female/52 male; $66 \mathrm{CU}$ and $49 \mathrm{MCl} / \mathrm{mild} \mathrm{AD}, 56 \mathrm{~A} \boldsymbol{\beta}+$ and NOTE: This preprint reports new research that has not been certified by peer review and should not be used to guide clinical practice. 
medRxiv preprint doi: https://doi.org/10.1101/2021.10.19.21264878; this version posted October 24,2021 . The copyright holder for this preprint (which was not certified by peer review) is the author/funder, who has granted medRxiv a license to display the preprint in

Fristed et al., 2021

All rights reserved. No reuse allowed without permission.

$59 \mathrm{~A} \boldsymbol{\beta}-)$. Using an average of 2.7 minutes of automatically transcribed speech from immediate recall of short stories, the $\mathrm{Al}$ system predicted $\mathrm{MCl} / \mathrm{mild} \mathrm{AD}$ in the full sample ( $\mathrm{AUC}=0.85+/-0.08)$, and amyloid in $\mathrm{MCl} / \mathrm{mild} \mathrm{AD}(\mathrm{AUC}=0.73+/-0.14)$ and $\mathrm{CU}$ subsamples $(A \cup C=0.71+/-0.13)$. Amyloid classification within the full sample was no better than chance $(A \cup C=0.57+/-0.11)$. Broadly similar results were reported for manually transcribed data, long ASRTs and delayed recall.

Interpretation: Combined with advanced Al language models, brief, remote speech-based testing offers simple, accessible and cost-effective screening for early stage AD.

Funding: Novoic.

\section{Research in context}

Evidence before this study: Recent systematic reviews have examined the use of speech data to detect vocal and linguistic changes taking place in Alzheimer's dementia. Most of this research has been completed in the DementiaBank cohort, where subjects are usually in the (more progressed) dementia stages and without biomarker confirmation of Alzheimer's disease (AD). Whether speech assessment can be used in a biomarker-confirmed, early stage (preclinical and prodromal) AD population has not yet been tested. Most prior work has relied on extracting manually defined "features", e.g. the noun rate, which has too low a predictive value to offer clinical utility in an early stage AD population. In recent years, audioand text-based machine learning models have improved significantly and a few studies have used such models in the context of classifying $A D$ dementia. These approaches could offer greater sensitivity but it remains to be seen how well they work in a biomarker-confirmed, early stage $A D$ population. Most studies have relied on controlled research settings and on manually transcribing speech before analysis, both of which limit broader applicability and use in clinical practice.

Added value of this study: This study tests the feasibility of advanced speech analysis for clinical testing of early stage AD. We present the results from a cross-sectional sample in the UK examining the predictive ability of fully automated speech-based testing in biomarkerconfirmed early stage Alzheimer's disease. We use a novel artificial intelligence (Al) system, which delivers sensitive indicators of $A D$-at-risk or subtle cognitive impairment. The $\mathrm{Al}$ system differentiates amyloid beta positive and amyloid beta negative subjects, and subjects with mild cognitive impairment $(\mathrm{MCl})$ or mild $A D$ from cognitively healthy subjects.

Importantly the system is fully remote and self-contained: participants' own devices are used for test administration and speech capture. Transcription and analyses are automated, with limited signal loss. Overall the results support the real-world applicability of speech-based 
medRxiv preprint doi: https://doi.org/10.1101/2021.10.19.21264878; this version posted October 24,2021 . The copyright holder for this preprint (which was not certified by peer review) is the author/funder, who has granted medRxiv a license to display the preprint in

Fristed et al., 2021

All rights reserved. No reuse allowed without permission.

assessment to detect early stage Alzheimer's disease. While a number of medical devices have recently been approved using image-based Al algorithms, the present research is the first to demonstrate the use case and promise of speech-based Al systems for clinical practice.

Implications of all the available evidence: Prior research has shown compelling evidence of speech- and language-based changes occurring in more progressed stages of Alzheimer's disease. Our study builds on this early work to show the clinical utility and feasibility of speech-based Al systems for the detection of Alzheimer's disease in its earliest stages. Our work, using advanced Al systems, shows sensitivity to a biomarker-confirmed early stage $A D$ population. Speech data can be collected with self-administered assessments completed in a real world setting, and analysed automatically. With the first treatment for $A D$ entering the market, there is an urgent need for scalable, affordable, convenient and accessible testing to screen at-risk subject candidates for biomarker assessment and early cognitive impairment. Sensitive speech-based biomarkers may help to fulfil this unmet need.

\section{Introduction}

Pathological changes in Alzheimer's disease (AD) begin years before symptoms of dementia or the early clinical stages of mild cognitive impairment $(\mathrm{MCl})$, and up to decades before diagnosis ${ }^{1}$. Clinical trials targeting the earliest stages of $A D$ typically rely on measuring Amyloid beta $(A \boldsymbol{\beta})$ biomarkers using positron emission tomography (PET) or in cerebrospinal fluid (CSF) obtained from lumbar puncture. The high cost and/or invasive nature of these procedures restricts use in standard clinical care and broader population screening. Blood plasma biomarkers hold promise for reducing screening costs but remain invasive and do not differentiate clinical stages of the disease ${ }^{2}$.

More importantly, cognitively unimpaired individuals with biomarker evidence of both amyloid beta and tau pathology will not always develop clinical manifestations in their lifetime, and should only be considered at-risk for progression to $A D$, reserving diagnosis of $A D$ to people with evidence of an $A D$ cognitive phenotype ${ }^{3}$. Cognitive testing is thus crucial for an early diagnosis. Cognitive tests have been supported for use as endpoints of treatment efficacy early in the Alzheimer's continuum by regulatory bodies ${ }^{4,5}$. However, traditional cognitive tests typically require significant qualified staff time to administer and score. In the case of amyloid 
medRxiv preprint doi: https://doi.org/10.1101/2021.10.19.21264878; this version posted October 24,2021 . The copyright holder for this preprint (which was not certified by peer review) is the author/funder, who has granted medRxiv a license to display the preprint in

Fristed et al., 2021

All rights reserved. No reuse allowed without permission.

positive asymptomatic subjects, only subtle impairments or longitudinal change are observable ${ }^{6,7}$.

Cognitive test results often reflect simple indices of response accuracy or recall, ignoring differences in the content, structure and delivery of patients' responses to tasks. For episodic memory tests, such as tests of story recall, test performance does not typically differ between clinically unimpaired $A \boldsymbol{\beta}+$ and $A \boldsymbol{\beta}$-individuals, but differences can be seen in the recall of proper nouns ${ }^{8}$, and the serial position of elements recalled ${ }^{9}$. Later in the disease course, differences are seen in rates of verbatim or paraphrased recall ${ }^{10}$, language density and pauses ${ }^{11}$.

There is a need for cognitive screening tools allowing fast and frequent assessment of the atrisk population. Speech data collected on ubiquitous digital devices represents an excellent candidate for this goal. Verbal memory tasks can be scored automatically using natural language processing technologies ${ }^{12}$, and augmented with acoustic and linguistic measures to further improve detection ${ }^{11}$. Recent methods in artificial intelligence (AI) enable extraction of more information-dense patterns from text data ${ }^{13,14}$. We hypothesise that these could form the basis of speech biomarkers sensitive to earlier disease stages, possibly before overt cognitive decline (asymptomatic at-risk individuals).

Using speech elicited from a remotely self-administered story recall task, we aim to develop an $\mathrm{Al}$-based system to (1) differentiate $\mathrm{A} \boldsymbol{\beta}$ + and $\mathrm{A} \boldsymbol{\beta}$ - subjects; (2) differentiate those with and without mild cognitive impairment. The test would be usable remotely for initial clinical screening to detect $\mathrm{MCl}$ and subtle signs of cognitive decline in amyloid-confirmed asymptomatic subjects (preclinical $A D$ ). Furthermore, we examine the performance of the index test compared to current standard-of-care in primary care referrals for $\mathrm{MCl}$ using a simulation approach.

\section{Methods}

\section{Study Design}

The AMYPRED study (NCT04828122) is a prospective study with data collection planned before the index test was performed. The study uses a $2 \times 2$ cross-sectional design, combining amyloid status ( $\mathrm{A} \boldsymbol{\beta}+$ and $\mathrm{A} \boldsymbol{\beta}$-) and clinical status (cognitively unimpaired $(\mathrm{CU})$ and $\mathrm{MCl} /$ mild $\mathrm{AD}$ ). Reference standards for $A \boldsymbol{\beta}$ positivity and clinical status were established prior to recruitment into the study. 
medRxiv preprint doi: https://doi.org/10.1101/2021.10.19.21264878; this version posted October 24,2021 . The copyright holder for this preprint (which was not certified by peer review) is the author/funder, who has granted medRxiv a license to display the preprint in

Fristed et al., 2021 All rights reserved. No reuse allowed without permission.

\section{Participants}

Participants were a convenience sample recruited from trial participant registries in three UK sites (London/Guildford, Plymouth and Birmingham) between November 2020 to July 2021. Subjects were approached if they had undergone a prior A $\boldsymbol{\beta}$ PET scan or CSF test (confirmed $A \boldsymbol{\beta}$ - within 30 months or $A \boldsymbol{\beta}+$ within 60 months) and were cognitively unimpaired (CU) or diagnosed with $\mathrm{MCl}$ or mild $\mathrm{AD}$ in the previous 5 years. $\mathrm{MCl}$ due to $\mathrm{AD}$ and mild $\mathrm{AD}$ diagnoses were made following National Institute of Aging-Alzheimer's Association core clinical criteria ${ }^{15}$.

Potential participants were screened via video conferencing, during which the Mini-Mental State Exam (MMSE) ${ }^{16}$ was administered. Inclusion criteria comprised: age 50-85; MMSE score 23-30 for participants with $\mathrm{MCl} / \mathrm{mild} \mathrm{AD}, 26-30$ for $\mathrm{CU}$; clinical diagnosis made in previous 5 years for participants with $\mathrm{MCl} /$ mild $\mathrm{AD}$; English as a first language; availability of a caregiver or close associate to support completing the Clinical Dementia Rating scale (CDR) semi-structured interview ${ }^{17}$; ability to use and access to a smartphone (Android 7 or above or iOS 11 or above); and access to the internet on a personal computer, notebook or tablet (supported operating systems and internet browser software documented in supplementary materials).

Exclusions comprised: current diagnosis of general anxiety disorder or major depressive disorder; recent (6-month) history of unstable psychiatric illness; history of stroke within the past 2 years or transient ischaemic attack or unexplained loss of consciousness in the last 12 months. Participants taking medications for $A D$ symptoms were required to be on a stable dose for at least 8 weeks.

\section{Study assessments}

Participants underwent a clinical assessment via video call, followed by optional remote assessments daily using their personal digital devices for 7-8 days.

\section{Telemedicine assessments}

Cognitive tests part of the Preclinical Alzheimer's Cognitive Composite with semantic processing (PACC5) were administered and mean z-score was calculated as previously described ${ }^{6}$. The $C D R^{17}$, assessing the severity of cognitive symptoms of dementia, was completed by experienced research staff and scored to deliver the CDR Global Score (CDR$\mathrm{G})$. Task modifications enabling remote assessment during the SARS-CoV-2 pandemic are detailed in supplementary materials. 
medRxiv preprint doi: https://doi.org/10.1101/2021.10.19.21264878; this version posted October 24,2021 . The copyright holder for this preprint (which was not certified by peer review) is the author/funder, who has granted medRxiv a license to display the preprint in

Fristed et al., 2021 All rights reserved. No reuse allowed without permission.

\section{Remote assessments}

During telemedicine assessments, participants were supported to install the Novoic mobile application on their own smartphone. They were encouraged to complete optional unsupervised self-assessments daily for the following 7-8 days. Remote self-assessments included Automatic Story Recall Tests (ASRT), consisting of 18 short and 18 long story variants (mean of 119 and 224 words per story, and stimulus duration approx 1 minute and $1 \mathrm{~min} 40$ seconds, respectively). ASRTs were administered in triplets (three stories administered consecutively each day). The self-assessment schedule is provided in supplementary materials.

Participants listened to pre-recorded ASRTs and retold stories in as much detail as they could remember, immediately after presentation of each story and after a delay. Task responses were recorded on the app and automatically uploaded to a secure server.

\section{Sample size determination}

Minimal bounds were set on the dataset size required to train flexible models with many parameters but strong representations (20 participants per group). Power calculations completed using the $\mathrm{pROC}$ package in $\mathrm{R}$, with power specified at $80 \%$ and significance set at 0.05 , indicated that for full sample analyses an AUC of 0.67 would be detectable with $\mathrm{n}=40$ participants in each group. Using similar parameters, an AUC of 0.74 would be detectable with a $\mathrm{n}=20$ participants in smaller subgroup analyses.

\section{Outcome measures}

Key outcome measures included the Al-based index test result, identifying: (1) A $\boldsymbol{\beta}$ positivity in the full sample; (2) $\mathrm{MCl}$ in the full sample; (3) $\mathrm{A} \boldsymbol{\beta}$ positivity in $\mathrm{MCl} / \mathrm{mild} \mathrm{AD}$; (4) $\mathrm{A} \boldsymbol{\beta}$ positivity in the CU subsample. Furthermore, an Al-based continuous measure predicting PACC5 scores was derived. Diagnostic accuracy was established through comparison with PET or CSF A $\boldsymbol{\beta}$ status and clinical diagnosis established in prior trials.

Short ASRT triplets (immediate recall, automatically transcribed) were primary measures of interest. These were experienced as lower burden by participants, yielding higher compliance and a greater number of datapoints for model training and analysis. Long ASRT stories and delayed recall were also examined.

\section{Oversight}


medRxiv preprint doi: https://doi.org/10.1101/2021.10.19.21264878; this version posted October 24,2021 . The copyright holder for this preprint (which was not certified by peer review) is the author/funder, who has granted medRxiv a license to display the preprint in

Fristed et al., 2021

All rights reserved. No reuse allowed without permission.

This study was approved by Institutional Review at the West Midlands Health Research Authority (UK REC reference: 20/WM/0116). Informed consent was taken electronically in accordance with HRA guidelines.

\section{Overview of the Al system}

The Al system was based on the "edit encoder" of the ParaBLEU model ${ }^{18}$, the state-of-theart for paraphrase evaluation. Given two input texts, the edit encoder outputs a vector-based representation of the abstract, generalized patterns that differ between them. On an established paraphrase quality benchmark, models using ParaBLEU numerical representations correlate more strongly with human judgements than other existing metrics ${ }^{18}$. Differing from the standard ParaBLEU setup, the model was pretrained with longer paraphrase examples to mirror the length of source-retelling pairs, and without the entailment component of the loss function as entailment labels were unavailable for the updated pretraining dataset. The base model of the edit encoder used a pretrained Longformer model rather than a pretrained RoBERTa model, to accommodate longer texts.

\section{Statistical analysis}

\section{Al system application}

Although adherence varied across participants, ASRTs have high parallel forms reliability, and modest practice effects, indicating that story triplets can be substituted for one another (Skirrow et al., submitted) $)^{19}$. One complete long and one complete short triplet (comprising six retellings per triplet: three immediate and three delayed) were picked randomly and uniformly for each participant across assessment days for onward analysis. Long and short triplets and immediate and delayed recall were examined separately.

Responses were transcribed manually and with an out-of-the-box automatic speech recognition (ASR) system. Analyses were completed in Python, using a proprietary framework built using PyTorch.

For each retelling, two representations were derived, based on non-redundant differences between the target (story text) and retelling (target $\rightarrow$ retelling and retelling $\rightarrow$ target) as represented by the ParaBLEU model. Classifiers were trained using logistic regression models with the sklearn package in Python to predict pairs of labels $(\mathrm{MCl} / \mathrm{mild} \mathrm{AD}$ or $\mathrm{CU}$; $A \boldsymbol{\beta}+$ or $A \boldsymbol{\beta}$-) with tournament leave-pair-out cross-validation analysis (TLPO) ${ }^{20}$. The TLPO process was run twice - once per representation - to obtain two sets of participant-level scores. These are ensembled by simple averaging. To augment the training sample, participants completing any remote assessments (including only partially completed ASRT 
medRxiv preprint doi: https://doi.org/10.1101/2021.10.19.21264878; this version posted October 24,2021 . The copyright holder for this preprint (which was not certified by peer review) is the author/funder, who has granted medRxiv a license to display the preprint in All rights reserved. No reuse allowed without permission.

Fristed et al., 2021

triplets) were included in model training. Predictions were tested only on participants with complete data.

\section{Clinical and biomarker discrimination of models}

Participant-level scores were ensembled across the three stories per triplet (immediate or delayed recall) to create participant level predictions. These were used to create a ranking for receiver operating characteristic (ROC) curve analysis. The Al system was compared to two comparison models, (1) a demographic comparison (age, sex and years of education) and (2) the PACC5 z-score. For $n=1 \mathrm{CU}$ participant, missing data for years in education was replaced with the group median. Comparison models were trained using the participant information as input(s) to a logistic regression model using an identical setup to the models trained on top of the ParaBLEU representations. Predictions were assessed by the area under the curve (AUC); and sensitivity, specificity and Cohen's kappa at Youden's index for the test result in comparison with reference standards. Statistical significance of differences between AUCs and 95\% confidence intervals for AUCs were computed using DeLong's method $^{21}$.

\section{PACC5 prediction}

PACC5 z-scores were predicted from speech samples, trained with leave-one-out crossvalidation using ridge regression models with polynomial kernels. The Pearson correlation coefficient between predicted and actual PACC5 scores was computed.

\section{Screening simulation}

Screening for $\mathrm{MCl}$ was simulated in a hypothetical age $65+$ sample $(n=1000)$ with proportional representation of each age group representative of the US population ${ }^{22}$, and $\mathrm{MCI}$ prevalence estimates by age from prior meta-analysis ${ }^{23}$. The Al system's (short stories, immediate recall, ASR) sensitivity and specificity within the sample was determined at Youden's index, and compared to physician subjective judgement and MMSE reported in prior research ${ }^{24}$. Methods are described in supplementary materials.

\section{Role of funding source}

The study was funded by Novoic, a clinical late-stage digital medtech company developing Al-based speech biomarkers. The funder of the study provided financial support towards collection and analysis of the data and was involved in study design, data interpretation and writing of the report. 
medRxiv preprint doi: https://doi.org/10.1101/2021.10.19.21264878; this version posted October 24, 2021. The copyright holder for this preprint (which was not certified by peer review) is the author/funder, who has granted medRxiv a license to display the preprint in All rights reserved. No reuse allowed without permission.

Fristed et al., 2021

\section{Results}

Participant recruitment is presented in figure 1. One hundred and thirty-three participants were recruited and completed study visits via video call, with $86 \%$ with $A \boldsymbol{\beta}$ status confirmed by PET scan (115/133). The MCl/mild AD participant group comprised primarily $\mathrm{MCl}$ participants, with ten individuals $(20.4 \%)$ having a diagnosis of mild AD.

At least one full optional remote self-assessment was completed by $86 \%$ (115/133). For those who engaged in at least one full optional remote self-assessment, overall engagement with daily testing was high (mean of $77 \%$ in full sample; $78 \%$ in $\mathrm{CU}$ and $66 \%$ in $\mathrm{MCl} / \mathrm{mild}$ $A D)$.

Those who did not complete remote assessments were more commonly diagnosed with $\mathrm{MCl} / \mathrm{mild} \mathrm{AD}\left(\mathrm{X}^{2}=5.49, \mathrm{p}=0.01\right)$ and had lower CDR-G scores $(r=-0.19, \mathrm{p}=0.04)$. However, they did not differ in age $(r=-0.15, p-0.12)$, education level $(r=-0.005, p=0.96)$, male/female ratio $\left(X^{2}=0.004, p=0.95\right), A \beta+/ A \beta$ - ratio $\left(X^{2}=0.96, p=0.33\right)$ or MMSE score $(r=-0.15, p=0.11)$. 
medRxiv preprint doi: https://doi.org/10.1101/2021.10.19.21264878; this version posted October 24, 2021. The copyright holder for this preprint (which was not certified by peer review) is the author/funder, who has granted medRxiv a license to display the preprint in perpetuity.

Fristed et al., 2021

All rights reserved. No reuse allowed without permission.

\section{A Reference standard selection}

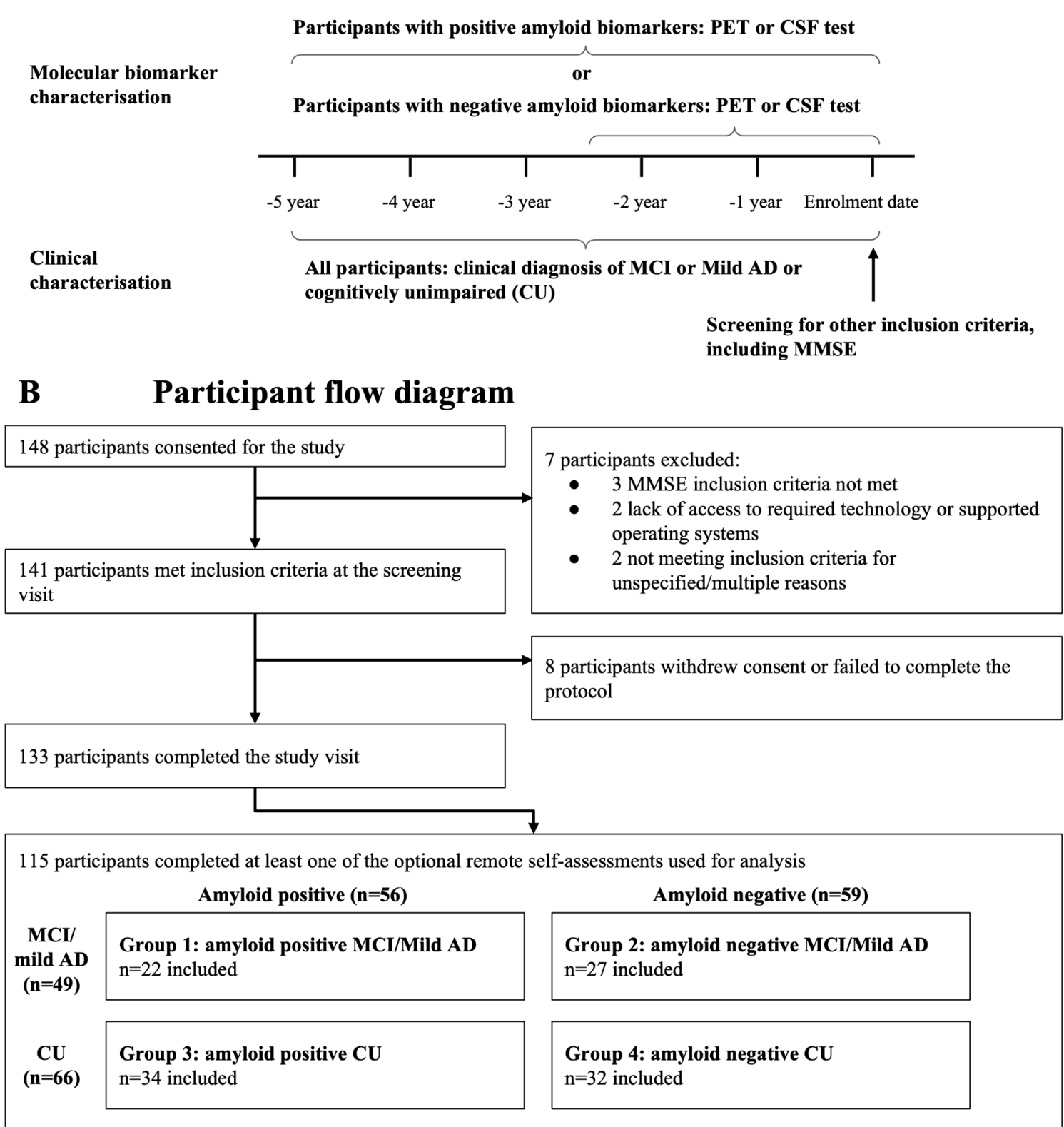

\section{Figure 1: Patient and reference standard selection}

(A) Participant inclusion criteria: participants were included based on prior amyloid status and clinical diagnosis confirmation before being screened for the study's other inclusion criteria. (B) Participant flow diagram, documenting exclusions and dropouts during study recruitment. PET: positron emission tomography; CSF: cerebrospinal fluid; $\mathrm{CU}$ : cognitively unimpaired; $\mathrm{MCl}$ : mild cognitive impairment; $\mathrm{AD}$ : Alzheimer's disease; MMSE: Mini-Mental State Exam

Demographics in the remote assessment sample (for subgroup and full sample analyses) are shown in table 1. This shows no clear differences between research, clinical and biomarker groups. Demographics for the entire sample and by short and long ASRT training sets are given in supplementary tables s3-s5. 
medRxiv preprint doi: https://doi.org/10.1101/2021.10.19.21264878; this version posted October 24, 2021. The copyright holder for this preprint (which was not certified by peer review) is the author/funder, who has granted medRxiv a license to display the preprint in perpetuity.

Fristed et al., 2021

All rights reserved. No reuse allowed without permission.

\begin{tabular}{|c|c|c|c|c|c|c|c|c|c|c|c|}
\hline & \multicolumn{5}{|c|}{ Subgroup analyses } & \multicolumn{6}{|c|}{ Full sample analyses } \\
\hline & \multirow{2}{*}{$\begin{array}{l}\text { Group 1: } \\
(\mathrm{N}=22)\end{array}$} & \multirow{2}{*}{$\begin{array}{l}\text { Group 2: } \\
(\mathrm{N}=27)\end{array}$} & \multirow{2}{*}{$\begin{array}{l}\text { Group 3: } \\
(\mathrm{N}=34)\end{array}$} & \multirow{2}{*}{$\begin{array}{l}\text { Group 4: } \\
(\mathrm{N}=32)\end{array}$} & \multirow[t]{2}{*}{$p$-value } & \multicolumn{3}{|c|}{ Clinical group } & \multicolumn{3}{|c|}{ Biomarker group } \\
\hline & & & & & & \begin{tabular}{|c|}
$\mathrm{CU}$ \\
$(\mathrm{N}=66)$
\end{tabular} & $\begin{array}{c}\mathrm{MCl} / \mathrm{mild} \\
\text { (AD } \\
\mathrm{N}=49 \text { ) }\end{array}$ & $p$-value & $\begin{array}{c}\text { Amyloid } \\
\text { beta } \\
\text { negative } \\
(\mathrm{N}=59)\end{array}$ & \begin{tabular}{|c|} 
Amyloid \\
beta \\
positive \\
$(\mathrm{N}=56)$
\end{tabular} & $p$-value \\
\hline $\begin{array}{l}\text { Amyloid beta } \\
\text { positive/ } \\
\text { negative }(\mathrm{N})\end{array}$ & Positive & Negative & Positive & Negative & - & $34 / 32$ & $22 / 27$ & 0.48 & Negative & Positive & - \\
\hline $\begin{array}{c}\mathrm{MCl} / \mathrm{CU} \\
\text { group }(\mathrm{N})\end{array}$ & $\begin{array}{c}\text { MCI/Mild } \\
\text { AD }\end{array}$ & $\begin{array}{c}\text { MCI/Mild } \\
\text { AD }\end{array}$ & $\mathrm{CU}$ & $\mathrm{CU}$ & - & CU & $\mathrm{MCl}$ & - & $27 / 32$ & $22 / 34$ & 0.48 \\
\hline $\begin{array}{c}\text { Female/male } \\
(\mathrm{N})\end{array}$ & $7 / 15$ & $16 / 11$ & $21 / 13$ & $19 / 13$ & 0.12 & $40 / 26$ & $23 / 26$ & 0.15 & $35 / 24$ & $28 / 28$ & 0.32 \\
\hline $\begin{array}{l}\text { Years in } \\
\text { education, } \\
\text { mean (SD) }\end{array}$ & $\begin{array}{l}15.05 \\
(3.32)\end{array}$ & $\begin{array}{l}15.08 \\
(2.92)\end{array}$ & $\begin{array}{l}14.97 \\
(3.77)\end{array}$ & $\begin{array}{l}15.41 \\
(3.35)\end{array}$ & 0.98 & $\begin{array}{c}15.18 \\
(3.55)\end{array}$ & $\begin{array}{l}15.06 \\
(3.08)\end{array}$ & 0.78 & $\begin{array}{l}15.26 \\
(3.14)\end{array}$ & $\begin{array}{l}15.00 \\
(3.57)\end{array}$ & 0.78 \\
\hline $\begin{array}{l}\text { Age, mean } \\
\text { (SD) }\end{array}$ & $\begin{array}{l}71.00 \\
(5.83)\end{array}$ & $\begin{array}{l}67.22 \\
(7.95)\end{array}$ & $\begin{array}{l}70.44 \\
(4.18)\end{array}$ & $\begin{array}{l}69.84 \\
(3.78)\end{array}$ & 0.38 & $\begin{array}{l}70.15 \\
(3.97)\end{array}$ & $\begin{array}{l}68.92 \\
(7.26)\end{array}$ & 0.74 & $\begin{array}{l}68.64 \\
(6.14)\end{array}$ & $\begin{array}{l}70.66 \\
(4.85)\end{array}$ & 0.13 \\
\hline $\begin{array}{c}\text { MMSE, mean } \\
\text { (SD) }\end{array}$ & $\begin{array}{l}27.27^{\mathrm{A}} \\
(1.64)\end{array}$ & $\begin{array}{l}27.41^{\mathrm{B}} \\
(2.02)\end{array}$ & $\begin{array}{l}29.24^{C} \\
(1.05)\end{array}$ & $\begin{array}{l}28.81^{\mathrm{D}} \\
(1.11)\end{array}$ & $\begin{array}{c}<0.001 \\
A C, A D, B C, \\
\text { BD }\end{array}$ & $\begin{array}{l}29.03 \\
(1.09)\end{array}$ & $\begin{array}{l}27.33 \\
(1.85)\end{array}$ & $<0.001$ & $\begin{array}{l}28.15 \\
(1.73)\end{array}$ & $\begin{array}{l}28.46 \\
(1.62)\end{array}$ & 0.25 \\
\hline $\begin{array}{l}\text { CDR-G, } \\
\text { mean }(S D)\end{array}$ & $\begin{array}{l}0.52^{\mathrm{A}} \\
(0.11)\end{array}$ & $\begin{array}{l}0.50^{\mathrm{B}} \\
(0.14)\end{array}$ & $\begin{array}{l}0.08^{C} \\
(0.18)\end{array}$ & $\begin{array}{l}0.10^{\mathrm{D}} \\
(0.20)\end{array}$ & $\begin{array}{c}<0.001 \\
\mathrm{AC}, \mathrm{AD}, \mathrm{BC}, \\
\mathrm{BD}\end{array}$ & $\begin{array}{c}0.09 \\
(0.19)\end{array}$ & $\begin{array}{c}0.51 \\
(0.12)\end{array}$ & $<0.001$ & $\begin{array}{c}0.28 \\
(0.27)\end{array}$ & $\begin{array}{l}0.25 \\
(0.27)\end{array}$ & 0.54 \\
\hline
\end{tabular}

Table 1: Participant demographic and clinical characteristics.

Demographic and clinical characteristics shown by research groupings 1-4, and summary statistics for participants characterised by clinical diagnostic or biomarker profiles. $\mathrm{MCl}$ : mild cognitive impairment; AD: Alzheimer's dementia; CU: cognitively unimpaired; N, number; SD, standard deviation. Group 1: amyloid beta

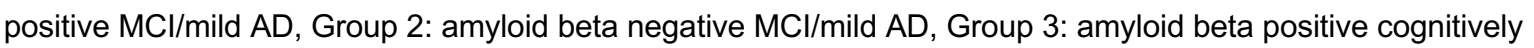
unimpaired; Group 4: amyloid beta negative cognitively unimpaired; MMSE: Mini-Mental State Exam; CDR-G: Clinical Dementia Rating Scale - Global Score.

\section{Outcome measures}

Al system application

$A \boldsymbol{\beta}$ classification in the full sample was no better than chance across the Al system and the two comparison analyses (figure 2A). Within the $\mathrm{MCI}$ (figure $2 \mathrm{C}$ ) and $\mathrm{CU}$ (figure 2D) subsamples the $A$ l system $A \cup C$ for $A \boldsymbol{\beta}$ detection was 0.73 , and 0.71 respectively, showing 
medRxiv preprint doi: https://doi.org/10.1101/2021.10.19.21264878; this version posted October 24, 2021. The copyright holder for this preprint (which was not certified by peer review) is the author/funder, who has granted medRxiv a license to display the preprint in All rights reserved. No reuse allowed without permission.

Fristed et al., 2021

better $\mathrm{A} \boldsymbol{\beta}$ signal when examined within more homogeneous groups. $\mathrm{MCl}$ classification using the $\mathrm{Al}$ system in the full sample yielded an AUC of 0.85 (figure $2 \mathrm{~B}$ ).

Al system performance did not differ depending on automatic versus manual transcription, and results were broadly consistent for long ASRT stories and delayed recall (table 2; supplementary figures). Demographic comparison performed consistently worse than the Al system (figure 2, table 2), with confidence intervals incorporating chance level, with the exception of amyloid prediction in the $\mathrm{MCl}$ subsample. As compared with the Al system, the PACC5 comparison delivered subtly but non-significantly higher AUCs for detecting $\mathrm{MCl}$ in the full sample, but similar performance for $\mathrm{A} \boldsymbol{\beta}$ status in $\mathrm{MCl}$ and poorer performance for $\mathrm{A} \boldsymbol{\beta}$ status in CU (figure 2). 
medRxiv preprint doi: https://doi.org/10.1101/2021.10.19.21264878; this version posted October 24,2021 . The copyright holder for this preprint (which was not certified by peer review) is the author/funder, who has granted medRxiv a license to display the preprint in perpetuity.

Fristed et al., 2021

All rights reserved. No reuse allowed without permission.

- Al system (ASR) — Demographic baseline - PACC5 baseline
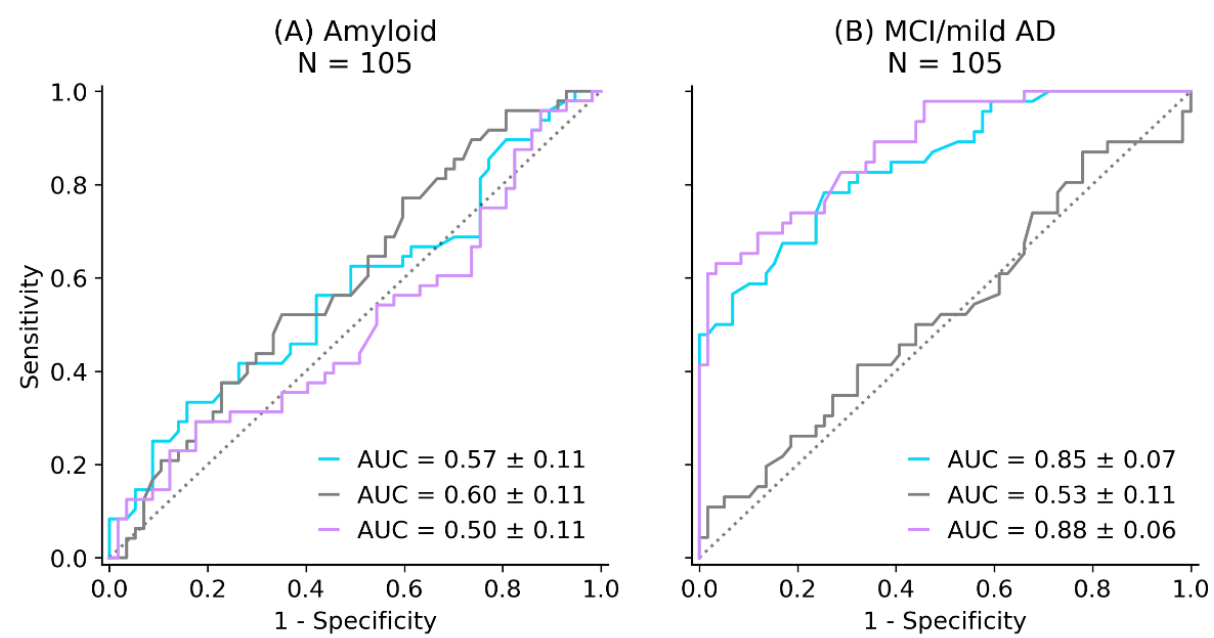

\begin{tabular}{|l|c|c|c|}
\cline { 2 - 4 } \multicolumn{1}{c|}{} & Sn & Sp & Cohen $\mathrm{k}$ \\
\hline Al (ASR) & 0.33 & 0.84 & 0.16 \\
\hline Demographic & 0.77 & 0.40 & 0.13 \\
\hline PACC5 & 0.29 & 0.82 & 0.10 \\
\hline
\end{tabular}

\begin{tabular}{|l|c|c|c|}
\cline { 2 - 4 } \multicolumn{1}{c|}{} & Sn & Sp & Cohen $\mathrm{k}$ \\
\hline Al (ASR) & 0.78 & 0.75 & 0.50 \\
\hline Demographic & 0.11 & 0.98 & 0.08 \\
\hline PACC5 & 0.63 & 0.97 & 0.60 \\
\hline
\end{tabular}

(C) Amyloid ( $\mathrm{MCl} / \mathrm{mild} \mathrm{AD})$

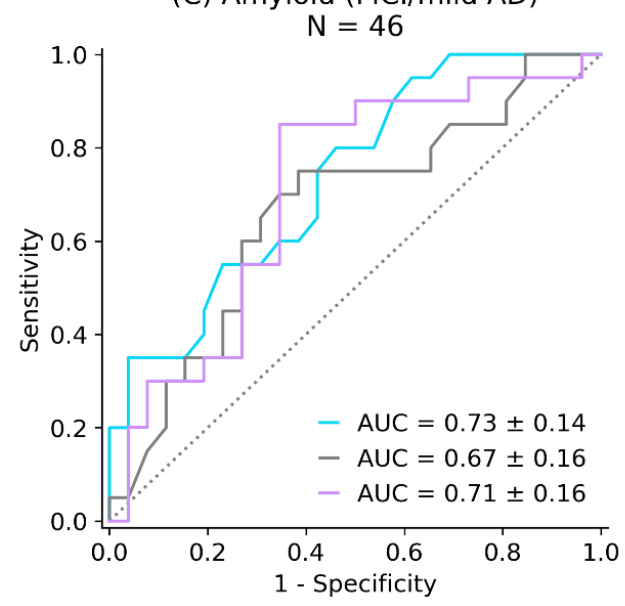

\begin{tabular}{|l|c|c|c|}
\cline { 2 - 4 } \multicolumn{1}{c|}{} & Sn & Sp & Cohen $\mathrm{k}$ \\
\hline Al (ASR) & 0.80 & 0.54 & 0.32 \\
\hline Demographic & 0.75 & 0.62 & 0.31 \\
\hline PACC5 & 0.85 & 0.65 & 0.44 \\
\hline
\end{tabular}

(D) Amyloid (CU) $\mathrm{N}=59$

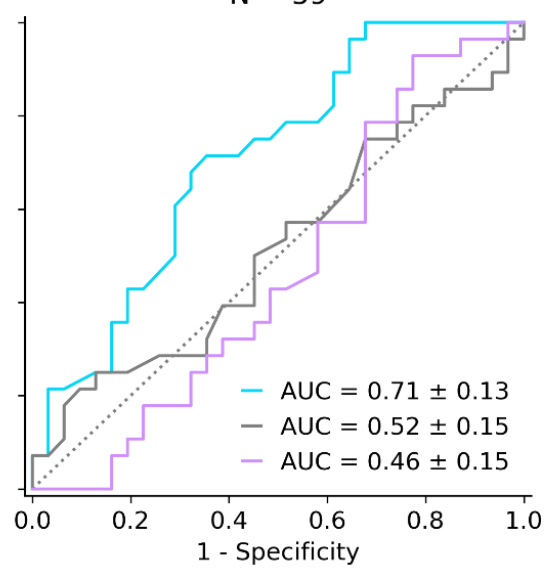

\begin{tabular}{|l|c|c|c|}
\cline { 2 - 4 } \multicolumn{1}{c|}{} & Sn & Sp & Cohen $\mathrm{k}$ \\
\hline Al (ASR) & 0.71 & 0.65 & 0.36 \\
\hline Demographic & 0.25 & 0.87 & 0.09 \\
\hline PACC5 & 0.93 & 0.23 & 0.11 \\
\hline
\end{tabular}

Figure 2: ROC curves for the Al system and comparison models (short ASRTs, immediate recall)

AUCs for the classifiers predicting: (A) amyloid, (B) MCl/mild AD in the full sample. Subsample comparisons of classifier performance predicting (C) amyloid within the MCl/mild AD; and (D) amyloid in the cognitively unimpaired $(\mathrm{CU})$ sample. The table below each figure provides sensitivity and specificity at Youden's index and Cohen's kappa measures. The reference test was biomarker confirmation on PET or CSF for A, C and D.

Reference test was clinical diagnosis MMSE inclusion criteria for $\mathrm{B}$. The demographic comparison includes age, 
medRxiv preprint doi: https://doi.org/10.1101/2021.10.19.21264878; this version posted October 24, 2021. The copyright holder for this preprint (which was not certified by peer review) is the author/funder, who has granted medRxiv a license to display the preprint in perpetuity.

Fristed et al., 2021

All rights reserved. No reuse allowed without permission.

sex and education level. ASR: automatic speech recognition - automatically transcribed; MCl: mild cognitive impairment; CU: cognitively unimpaired; Al: artificial intelligence; ASRT: automatic story recall test; PACC5: preclinical Alzheimer's cognitive composite with semantic processing; ROC: receiver operator characteristic (curve); AUC: area under the curve.

\begin{tabular}{|c|c|c|c|c|c|c|}
\hline Task type & Delay type & Model & $\begin{array}{c}\text { (A) Full } \\
\text { sample } \\
\text { amyloid beta }\end{array}$ & $\begin{array}{c}\text { (B) Full } \\
\text { sample } \mathrm{MCl}\end{array}$ & $\begin{array}{l}\text { (C) Amyloid } \\
\text { beta in } \mathrm{MCl} \\
\text { subsample }\end{array}$ & $\begin{array}{c}\text { (D) Amyloid } \\
\text { beta in CU } \\
\text { group }\end{array}$ \\
\hline \multirow{4}{*}{$\begin{array}{l}\text { Short } \\
\text { ASRT }\end{array}$} & \multirow{4}{*}{ Immediate } & Sample size & $n=105$ & $n=105$ & $n=46$ & $n=59$ \\
\hline & & Al system (ASR) & $0.57+/-0.11$ & $0.85+/-0.07^{*}$ & $0.73+/-0.14$ & $0.71+/-0.13$ \\
\hline & & Al system (manual) & $0.56+/-0.12$ & $0.83+/-0.08^{*}$ & $0.74+/-0.14$ & $0.69+/-0.13$ \\
\hline & & $\begin{array}{l}\text { Demographic } \\
\text { comparison }\end{array}$ & $0.60+/-0.11$ & $0.53+/-0.11$ & $0.67+/-0.16$ & $0.52+/-0.15$ \\
\hline \multirow{4}{*}{$\begin{array}{l}\text { Short } \\
\text { ASRT }\end{array}$} & \multirow{4}{*}{ Delayed } & Sample size & $n=105$ & $n=105$ & $n=46$ & $n=59$ \\
\hline & & Al system (ASR) & $0.59+/-0.11$ & $0.84+/-0.08^{*}$ & $0.68+/-0.16$ & $0.70+/-0.13$ \\
\hline & & Al system (manual) & $0.61+/-0.11$ & $0.83+/-0.08^{*}$ & $0.69+/-0.16$ & $0.71+/-0.14$ \\
\hline & & $\begin{array}{l}\text { Demographic } \\
\text { comparison }\end{array}$ & $0.60+/-0.11$ & $0.53+/-0.11$ & $0.67+/-0.16$ & $0.52+/-0.15$ \\
\hline \multirow{4}{*}{$\begin{array}{l}\text { Long } \\
\text { ASRT }\end{array}$} & \multirow{4}{*}{ Immediate } & Sample size & $n=97$ & $n=97$ & $n=39$ & $n=58$ \\
\hline & & Al system (ASR) & $0.59+/-0.12$ & $0.85+/-0.08^{*}$ & $0.85+/-0.13$ & $0.53+/-0.15$ \\
\hline & & Al system (manual) & $0.61+/-0.12$ & $0.87+/-0.07^{*}$ & $0.91+/-0.09$ & $0.59+/-0.15$ \\
\hline & & $\begin{array}{l}\text { Demographic } \\
\text { comparison }\end{array}$ & $0.62+/-0.11$ & $0.57+/-0.12$ & $0.75+/-0.16$ & $0.47+/-0.15$ \\
\hline \multirow{4}{*}{$\begin{array}{l}\text { Long } \\
\text { ASRT }\end{array}$} & \multirow{4}{*}{ Delayed } & Sample size & $n=97$ & $n=97$ & $n=39$ & $n=58$ \\
\hline & & Al system (ASR) & $0.55+/-0.12$ & $0.83+/-0.08^{*}$ & $0.86+/-0.12$ & $0.53+/-0.15$ \\
\hline & & Al system (manual) & $0.59+/-0.12$ & $0.85+/-0.08^{*}$ & $0.88+/-0.10$ & $0.50+/-0.15$ \\
\hline & & $\begin{array}{l}\text { Demographic } \\
\text { comparison }\end{array}$ & $0.62+/-0.11$ & $0.57+/-0.12$ & $0.75+/-0.16$ & $0.45+/-0.15$ \\
\hline
\end{tabular}

Table 2: Area under the curve (AUC +/- $95 \%$ confidence intervals) for ASRT variants and demographic comparison

Comparison of performance of the Al system for classifying (A) Amyloid beta in the full sample, (B) MCl in the full sample, (C) Amyloid beta in the $\mathrm{MCl}$ subsample, and (D) Amyloid beta in the CU subsample, using immediate and delayed recalls of short and long ASRT triplets as input. Difference between Al system and demographic comparison ${ }^{*} p<0.0001$. CU: cognitively unimpaired; MCl: mild cognitive impairment; ASRT: automatic story recall task; ASR: automatic speech recognition - automatically transcribed; manual: manually transcribed.

\section{$\underline{\text { PACC5 prediction }}$}


medRxiv preprint doi: https://doi.org/10.1101/2021.10.19.21264878; this version posted October 24,2021 . The copyright holder for this preprint (which was not certified by peer review) is the author/funder, who has granted medRxiv a license to display the preprint in

Fristed et al., 2021

All rights reserved. No reuse allowed without permission.

The Pearson correlation between Al-model predicted and actual PACC- 5 z scores was 0.74 .

\section{Simulation of $\mathrm{MCl}$ screening in primary care}

In a simulated population sample age $65+(\mathrm{MCl}$ prevalence $16 \%)$, in comparison with unassisted physician judgement ${ }^{24}$, routine screening using the Al system (short stories, immediate recall) would increase correct referral rates in primary care by $56.0 \%$, and reduce incorrect referrals by $26.5 \%$; in comparison with screening via the $\mathrm{MMSE}^{24}$ the $\mathrm{Al}$ system would increase correct referral from primary care by $52.9 \%$.

\section{Discussion}

Research documents changes in vocal and linguistic speech patterns in $A D$, primarily in cohorts with more progressed $A D$ and without biomarker confirmation ${ }^{13,25}$. The current findings show changes in speech occurring earlier in the disease process. Furthermore, we find modest but detectable differences in speech relating to changes associated with $A \boldsymbol{\beta}$ positivity.

For the lowest burden assessments (short stories, immediate recall), the Al system predicted $\mathrm{MCl}(\mathrm{AUC}$ 0.85) and $\mathrm{A} \boldsymbol{\beta}$ positivity in $\mathrm{MCl}$ and $\mathrm{CU}$ participant groups (AUC 0.73 and 0.71 , respectively), but with $A \boldsymbol{\beta}$ predictions in the full sample being no better than random. This could be due to more subtle impairments associated with $A \boldsymbol{\beta}$ positivity, which may be obscured by broader changes seen accompanying $\mathrm{MCl}$. The Al system consistently outperformed the demographic comparison and performed as well as, or better than, a lengthy supervised test battery developed to detect cognitive changes in preclinical AD (PACC5).

Al system results were consistent across manual and ASR transcription. $\mathrm{MCl}$ prediction was consistent for long and short ASRTs and immediate and delayed recall. A $\boldsymbol{\beta}$ status prediction was not as consistent across task variants and groups: in cognitively unimpaired participants the Al system performed well for short, but not long, ASRTs; predictions of $A \boldsymbol{\beta}$ status in $\mathrm{MCl}$ was above random for all task variants, but in the presence of an elevated demographic comparison. These results may indicate differential task difficulty effects interacting with demographic and clinical-biomarker groupings.

In the context of potential improvement in outcomes through lifestyle and medical interventions ${ }^{26}$, and the availability of new amyloid-targeting medications, early detection of $A D$ and clear disease indication matters. However, in clinical practice, $A D$ is not routinely 
medRxiv preprint doi: https://doi.org/10.1101/2021.10.19.21264878; this version posted October 24,2021 . The copyright holder for this preprint (which was not certified by peer review) is the author/funder, who has granted medRxiv a license to display the preprint in

Fristed et al., 2021

All rights reserved. No reuse allowed without permission.

screened for $^{27}$ and is underdiagnosed even at the dementia stage ${ }^{28}$. Compared with standard-of-care assessments for $\mathrm{MCl}$, routine screening using the $\mathrm{Al}$ system could increase correct referrals by up to $56.0 \%$ and reduce incorrect referrals by $26.5 \%$.

Speech assessments were unsupervised, self-administered and analysed with an automated pipeline. Remote, unsupervised testing can improve inclusivity, increase standardisation and provide access to more advanced testing without the need for extensive experience of neuropsychological workup. Furthermore, speech-based Al models present as a potentially attractive low-cost and low-burden screen for $A \boldsymbol{\beta}$ positivity. Combining the algorithm with other risk factors (e.g. age, APOE genotype) could further increase discriminative power.

\section{Limitations}

We recruited participants with prior amyloid PET and CSF amyloid test results and clinical diagnoses. With increasing $A \boldsymbol{\beta}$ positivity with age ${ }^{29}$, conversion may have occurred for some participants in the interim period. CSF and PET A $\boldsymbol{\beta}$ positivity are differentially associated with cognitive decline, suggesting that they may be optimally sensitive at different disease stages $^{30}$. Similarly, variation in diagnostic criteria for MCI/Mild AD (between trials where participants were recruited from) is likely to have introduced variability in our diagnostic reference standards. Even a small number of false labels can impact training of Al systems, and improvements in model performance could be expected with concurrent and consistent reference standards.

Although uptake of optional remote assessment was high, non-completion was associated with greater CDR-G indexed clinical impairment and was more common in MCI/Mild AD participants. Remote, unsupervised cognitive assessments may be challenging for individuals with more progressed cognitive impairment. For these subjects, supervised testing in clinic or via telemedicine may be more appropriate.

Test engagement varied from day to day and, as a result, our analyses included test results from different ASRT stimuli and testing days across different participants. Variability introduced by differences in the story stimuli themselves and practice effects, may have affected sensitivity of the Al system. However, this approach allowed us to maximise the sample available, and enabled us to develop stimulus-agnostic Al models, which can be applied across a class of stimuli.

Our Al system was developed and tested within a British English speaking sample, selected to exclude concurrent neurological and mental health conditions. Validation is now needed in 
medRxiv preprint doi: https://doi.org/10.1101/2021.10.19.21264878; this version posted October 24,2021 . The copyright holder for this preprint (which was not certified by peer review) is the author/funder, who has granted medRxiv a license to display the preprint in All rights reserved. No reuse allowed without permission.

Fristed et al., 2021

more clinically heterogeneous samples and across different accents and languages. Largerscale studies are needed to confirm and refine our results. We expect significant performance improvements in the Al system with a larger training dataset, increasing power to detect more subtle changes in speech patterns.

\section{Conflict of interest statement}

EF, JW, MM, CS, RL and UM are employees of Novoic Ltd. EF, JW and MM are shareholders and MM, RL, UM, and CS are option holders in the company. EF and JW are directors on the board of Novoic. SC has received speaker's fees from Roche and Biogen. DA has received research support and/or honoraria from Astra-Zeneca, Lundbeck, Novartis Pharmaceuticals, Evonik, Roche Diagnostics, and GE Health, and served as paid consultant for H. Lundbeck, Eisai, Heptares, Mentis Cura, Eli Lilly, Cognetivity, Enterin, Acadia, and Biogen.

\section{Author contributions}

The study protocol was designed by EF, MM, and JW. The research study and data collection was coordinated by MM. Software was developed by JW, UM, RL and EF. Underlying data was verified by all authors (data acquisition and completeness MM, database management UM, quality control CS, data generated by analytic models JW, EF, $\mathrm{UM}$, and RL). Analyses were completed by RL, CS, UM, JW, and EF. The first draft of the manuscript was completed by EF and CS. All authors contributed to the revision of the manuscript.

\section{Role of funding source}

The study was funded by Novoic, a clinical late-stage digital medtech company developing Al-based speech biomarkers. The funder of the study provided financial support towards collection and analysis of the data and was involved in study design, data interpretation and writing of the report.

\section{Data sharing}

Speech data is identifiable and cannot be shared, but all deidentified quantitative participant data shown in the present study are available upon reasonable request to the authors. 
medRxiv preprint doi: https://doi.org/10.1101/2021.10.19.21264878; this version posted October 24,2021 . The copyright holder for this preprint (which was not certified by peer review) is the author/funder, who has granted medRxiv a license to display the preprint in All rights reserved. No reuse allowed without permission.

Fristed et al., 2021

\section{References}

1 Villemagne VL, Burnham S, Bourgeat $P$, et al. Amyloid $\beta$ deposition, neurodegeneration, and cognitive decline in sporadic Alzheimer's disease: a prospective cohort study. Lancet Neurol 2013; 12: 357-67.

2 Tosun D, Veitch D, Aisen P, et al. Detection of $\beta$-amyloid positivity in Alzheimer's Disease Neuroimaging Initiative participants with demographics, cognition, MRI and plasma biomarkers. Brain Commun 2021; 3: fcab008.

3 Dubois B, Villain N, Frisoni GB, et al. Clinical diagnosis of Alzheimer's disease: recommendations of the International Working Group. Lancet Neurol 2021; 20: 484-96.

4 Kozauer N, Katz R. Regulatory innovation and drug development for early-stage Alzheimer's disease. N Engl J Med 2013; 368: 1169-71.

5 European Medicines Agency. Guideline on the clinical investigation of medicines for the treatment of Alzheimer's disease. 2018; published online Feb 22.

https://www.ema.europa.eu/en/documents/scientific-guideline/guideline-clinicalinvestigation-medicines-treatment-alzheimers-disease-revision-2_en.pdf (accessed April 12, 2021).

6 Papp KV, Rentz DM, Orlovsky I, Sperling RA, Mormino EC. Optimizing the preclinical Alzheimer's cognitive composite with semantic processing: The PACC5. Alzheimers Dement (N Y) 2017; 3: 668-77.

7 Baker JE, Lim YY, Pietrzak RH, et al. Cognitive impairment and decline in cognitively normal older adults with high amyloid- $\beta$ : A meta-analysis. Alzheimers Dement (Amst) 2017; 6: 108-21.

8 Mueller KD, Koscik RL, Du L, et al. Proper names from story recall are associated with beta-amyloid in cognitively unimpaired adults at risk for Alzheimer's disease. Cortex 2020; 131: 137-50.

9 Bruno D, Mueller KD, Betthauser T, et al. Serial position effects in the Logical Memory Test: Loss of primacy predicts amyloid positivity. J Neuropsychol 2020; published online Dec 4. DOI:10.1111/jnp.12235.

10 Foldi NS. Getting the hang of it: preferential gist over verbatim story recall and the roles of attentional capacity and the episodic buffer in Alzheimer disease. $J$ Int Neuropsychol Soc 2011; 17: 69-79.

11 Roark B, Mitchell M, Hosom J-P, Hollingshead K, Kaye J. Spoken language derived measures for detecting mild cognitive impairment. IEEE Trans Audio Speech Lang Processing 2011; 19: 2081-90.

12 Lehr M, Prud'hommeaux E, Shafran I, Roark B. Fully Automated Neuropsychological Assessment for Detecting Mild Cognitive Impairment . INTERSPEECH 2012 2012; published online Sept 9.

13 de la Fuente Garcia S, Ritchie C, Luz S. Artificial intelligence, speech, and language processing approaches to monitoring alzheimer's disease: A systematic review. J Alzheimers Dis 2020; published online Nov 6. DOI:10.3233/JAD-200888.

14 Weston J, Lenain R, Meepagama U, Fristed E. Learning De-identified Representations of Prosody from Raw Audio. In: Proceedings of the 38th International Conference on 
medRxiv preprint doi: https://doi.org/10.1101/2021.10.19.21264878; this version posted October 24,2021 . The copyright holder for this preprint (which was not certified by peer review) is the author/funder, who has granted medRxiv a license to display the preprint in All rights reserved. No reuse allowed without permission.

Fristed et al., 2021

Machine Learning. 2021: 11134-45.

15 Albert MS, DeKosky ST, Dickson D, et al. The diagnosis of mild cognitive impairment due to Alzheimer's disease: recommendations from the National Institute on AgingAlzheimer's Association workgroups on diagnostic guidelines for Alzheimer's disease. Alzheimers Dement 2011; 7: 270-9.

16 Folstein MF, Folstein SE, McHugh PR. "Mini-mental state" A practical method for grading the cognitive state of patients for the clinician. J Psychiatr Res 1975; 12: 189-98.

17 Morris JC. The Clinical Dementia Rating (CDR): current version and scoring rules. Neurology 1993; 43: 2412-4.

18 Weston J, Lenain R, Meepegama U, Fristed E. Generative Pretraining for Paraphrase Evaluation. arXiv 2021; published online July 24.

19 Skirrow C, Meszaros M, Meepegama U, et al. Validation of a novel fully automated story recall task for repeated remote high-frequency administration. MedrXiv 2021.

20 Airola A, Pahikkala T, Waegeman W, De Baets B, Salakoski T. An experimental comparison of cross-validation techniques for estimating the area under the ROC curve. Comput Stat Data Anal 2011; 55: 1828-44.

21 Sun X, Xu W. Fast implementation of delong's algorithm for comparing the areas under correlated receiver operating characteristic curves. IEEE Signal Process Lett 2014; 21: 1389-93.

22 Statista. Resident population of the United States by sex and age as of July 1, 2020. Resident population of the United States by sex and age as of July 1, 2020 (in millions). 2021; published online Sept 10. https://www.statista.com/statistics/241488/population-ofthe-us-by-sex-and-age/ (accessed Sept 27, 2021).

23 Petersen RC, Lopez O, Armstrong MJ, et al. Practice guideline update summary: Mild cognitive impairment: Report of the Guideline Development, Dissemination, and Implementation Subcommittee of the American Academy of Neurology. Neurology 2018; 90: 126-35.

24 Tong T, Thokala P, McMillan B, Ghosh R, Brazier J. Cost effectiveness of using cognitive screening tests for detecting dementia and mild cognitive impairment in primary care. Int $J$ Geriatr Psychiatry 2017; 32: 1392-400.

25 Martínez-Nicolás I, Llorente TE, Martínez-Sánchez F, Meilán JJG. Ten years of research on automatic voice and speech analysis of people with alzheimer's disease and mild cognitive impairment: A systematic review article. Front Psychol 2021; $12: 620251$.

26 Livingston G, Huntley J, Sommerlad A, et al. Dementia prevention, intervention, and care: 2020 report of the Lancet Commission. Lancet 2020; 396: 413-46.

27 Alzheimer's Association. 2019 Alzheimer's facts and figures. https://www.alz.org/media/documents/alzheimers-facts-and-figures-2019-r.pdf (accessed July 22, 2021).

28 Connolly A, Gaehl E, Martin H, Morris J, Purandare N. Underdiagnosis of dementia in primary care: variations in the observed prevalence and comparisons to the expected prevalence. Aging Ment Health 2011; 15: 978-84.

29 Jansen WJ, Ossenkoppele R, Knol DL, et al. Prevalence of cerebral amyloid pathology in 
medRxiv preprint doi: https://doi.org/10.1101/2021.10.19.21264878; this version posted October 24, 2021. The copyright holder for this preprint (which was not certified by peer review) is the author/funder, who has granted medRxiv a license to display the preprint in perpetuity.

Fristed et al., 2021

All rights reserved. No reuse allowed without permission.

persons without dementia: a meta-analysis. JAMA 2015; 313: 1924-38.

30 Guo T, Shaw LM, Trojanowski JQ, Jagust WJ, Landau SM, Alzheimer's Disease Neuroimaging Initiative. Association of CSF A $\beta$, amyloid PET, and cognition in cognitively unimpaired elderly adults. Neurology 2020; 95: e2075-85. 